\title{
A crise contemporânea do capitalismo: reflexões a partir de um debate com as abordagens sistêmicas de Arrighi, Fiori e Wallerstein *
}

\author{
Daniel Feldmann **
}

\begin{abstract}
Resumo
O artigo pretende trazer elementos relevantes para a apreensão do capitalismo contemporâneo, partindo da hipótese de que ele está sujeito a uma crise estrutural. Para tanto, o enfoque adotado atribui especial importância para a lógica de imposição do capital e seus dispositivos fetichistas que subordinam os diferentes países aos imperativos do processo de valorização capitalista. Tal enfoque é desenvolvido no bojo de um debate com as abordagens sistêmicas de Arrighi, Fiori e Wallerstein. Por articularem conjuntamente as esferas econômica, política e social do capitalismo, sugere-se que, tanto na exposição como também nas críticas cabíveis a tais abordagens, é possível trazer à tona questões importantes para o entendimento das transformações recentes.
\end{abstract}

Palavras-chave: Globalização; Economia política internacional; Relações internacionais; Imperialismo.

\begin{abstract}
The contemporary crisis of capitalism: a debate on the systemic approaches of Arrighi, Fiori and Wallerstein

The article intends to bring relevant elements to the apprehension of contemporary capitalism, starting from the hypothesis that it is subject to a structural crisis. To this end, our approach attaches particular importance to the logic of imposition of capital and its fetishistic devices that subordinate the different countries to the imperatives of the capitalist valorization process. This approach is developed in the context of a debate on the systemic approaches of Arrighi, Fiori and Wallerstein. By articulating jointly the economic, political and social spheres of capitalism, it is suggested that, both in the exposition and in the criticisms applicable to such approaches, it is possible to raise important questions for the understanding of recent transformations.
\end{abstract}

Keywords: Globalization; International political economy; International relations; Imperialism. JEL F500, F540, F600.

\section{As abordagens sistêmicas e a lógica de imposição do capital}

As abordagens sistêmicas postulam uma leitura histórica do capitalismo que articule num mesmo quadro as esferas econômica, social e política, bem como as hierarquias entre classes e nações.

Com ênfase na longa duração baseada em Sistemas, elas buscam a apreensão de uma totalidade condizente com a dinâmica e o evolver do capitalismo. Assim, as abordagens sistêmicas, por sua amplitude de enfoque, têm o mérito de pôr em tela aspectos cruciais como a dinâmica das relações internacionais, a interdependência de diferentes regiões, bem como suas assimetrias de poder e riqueza. Assim como têm a vantagem de buscar apreender em conjunto o movimento

\footnotetext{
* Artigo recebido em 6 de dezembro de 2017 e aprovado em 6 de abril de 2018.

${ }^{* *}$ Professor adjunto do Departamento de Economia da Universidade Federal de São Paulo (Unifesp), São Paulo, SP, Brasil. E-mail: dafeldbr@yahoo.com.br.
} 
de diferentes dimensões da vida social. Daí também que do ponto de vista epistemológico elas se esforcem por historicizar as ciências sociais. Para Wallerstein (2012, p. 22), isto sinaliza a necessidade de se superar o positivismo de disciplinas isoladas de forma estanque, instituindo um "movimento do saber" que unifique no pensamento as esferas separadas pelo conhecimento acadêmico tradicional.

Neste artigo travamos um debate com as contribuições de Arrighi, Wallerstein e Fiori. Tal escolha reside no fato de que cada um deles à sua maneira buscou pensar as mudanças recentes do capitalismo através de abordagens sistêmicas. ${ }^{1}$ Nosso objetivo não será o de investigar aqui o conjunto de seus trabalhos, mas sim de forma mais modesta, como cada um deles suscita questões relevantes para a análise contemporânea. Por meio da exposição e das críticas cabíveis às formulações dos autores, a meta principal deste trabalho é trazer à tona elementos relevantes que ajudem a iluminar as transformações em curso, transformações estas que parecem sinalizar uma crise estrutural do capitalismo. ${ }^{2}$ Nesta investigação, conferimos especial importância ao processo de imposição do capital e sua lógica. Ou seja, sem ter a pretensão de dar conta de todos os aspectos que envolvem o capitalismo contemporâneo, o ângulo de análise aqui escolhido consistirá em pensar como a difusão do processo incessante de "valorização do valor" que caracteriza o capital como relação social estrutura determinadas compulsões e exigências. Processo este cujo resultado é a mercantilização da sociedade e a tendência à transformação total da produção e reprodução econômicas em momentos do capital. E justamente por seu caráter pervasivo, trata-se de um processo em que se reformulam constantemente a sociabilidade, a política, a técnica, a cultura e as formas de pensamento. Em outras palavras, o processo de imposição do capital implica uma dinâmica societária que permeia as diferentes esferas da vida e que portanto não pode jamais ser reduzida ao "econômico".

Isto não significa ignorar que a origem histórica daquilo que os autores com os quais debateremos chamam de Sistema antecede em séculos a generalização dos processos acima descritos. O ponto a ser salientado é que mesmo se já havia um determinado Sistema como antessala do processo de imposição do capital, este último ao se desdobrar há de plasmar, impulsionar e dar sentido ao próprio Sistema. ${ }^{3}$ Com a lógica expansiva e irrefreável do capital

(1) Optamos aqui pela expressão "abordagens sistêmicas" pois ela dá conta da heterogeneidade dos três autores que debateremos no artigo. Pois se o conceito de Sistema-Mundo é usado nos trabalhos de Wallerstein e Arrighi, ele inexiste em Fiori. Este último trabalha com a ideia de Sistema Interestatal Capitalista por motivos que retomaremos depois. A noção de um Sistema Interestatal também se faz presente em Wallerstein e Arrighi. No entanto, ela faz parte de um conjunto maior que é o próprio Sistema-Mundo. "O sistema-mundo capitalista reúne uma economia-mundo capitalista e um conjunto de Estados nacionais em um sistema interestatal com múltiplas culturas" (Ariente; Filomeno, 2007, p. 103). Por outro lado a noção de "sistêmico" nos parece válida na medida que todos apreendem o capitalismo como um sistema histórico de longa duração, de caráter mundial e que deve ser pensado nas suas distintas esferas.

(2) A explicitação da nossa visão da crise estrutural do capitalismo se dará ao longo da seção 3.

(3) É verdade aqui que tal processo não é absoluto, nem isento de contradições. Por exemplo, como salienta Wallerstein (2001, p. 22-23), formas de trabalho estritamente proletárias sempre foram minoritárias, mesmo em períodos mais recentes, em especial na Periferia capitalista (Wallerstein, 2001, p.22-23). Mas isso não desautoriza a tendência que o capitalismo traz consigo no longo prazo de subordinar crescentemente os indivíduos aos imperativos da acumulação e do valor. A seguinte citação, do 
como "sujeito automático" (Marx, 1985, vol.1, p. 130) posta em marcha historicamente, barreiras foram transpostas e reforçou-se a integração - conflitiva e desigual - de todos os continentes. Ao tornar obrigatória a expansão das forças produtivas e das exportações de mercadorias e investimentos, o processo de unificação do mundo em torno do capital ganhou em escopo e abrangência. De forma análoga, a interdependência de diferentes regiões do globo, interdependência não apenas de indivíduos mas também de Estados, foi intensificada sobremaneira com a difusão de uma sociabilidade que torna a troca em mercados um imperativo e que elege o valor como forma definitiva e abstrata de riqueza. Penetrando e transformando diferentes regiões e paulatinamente submetendo-as às suas determinações, o capital foi se impondo e moldando as relações internacionais subjacentes ao Sistema.

A abordagem que estamos sugerindo é informada pela leitura de Marx feita por Postone (2014, p. 46) que postula que "a dominação social no capitalismo, no seu nível mais fundamental, não consiste na dominação das pessoas por outras pessoas, mas na dominação das pessoas por estruturas sociais abstratas constituídas pelas próprias pessoas". O que chamamos aqui de lógica de imposição do capital implica justamente neste processo de sujeição das pessoas a estruturas abstratas, mas que nem por isso são menos efetivas e reais no cotidiano prático dos indivíduos, justamente porque com isso "o caráter específico do trabalho(...) também constitui a base de uma forma historicamente específica, abstrata e impessoal de dominação social" (ibidem, 46). Ou seja, trata-se de pôr em relevo os desenvolvimentos oriundos da disseminação do trabalho abstrato que fazem com que a mediação social entre os indivíduos tome a forma do valor, ao mesmo tempo em que a expansão sem limite do valor torna-se o norte da atividade produtiva. Para Postone (2016, p. 16) este "valor em movimento" que caracteriza o capital, mesmo que criado a partir das interações entre as pessoas, acaba por criar mecanismos de controle sobre elas próprias. No que tange à problemática sistêmica aqui em debate, isso implica salientar a vigência de uma dinâmica fetichista que perpassa o capitalismo e suas relações internacionais e que exerce como força heterônoma uma constante coação sobre os diferentes atores e Estados Nacionais.

Antes de finalizarmos esta seção, dois breves comentários. Primeiramente, o enfoque descrito acima não significa desconsiderar a importância da agência e das margens de escolha de indivíduos e Estados. Trata-se meramente de termos em conta que no capitalismo tais ações e escolhas sempre estão constrangidas por um poder alheio e independente da vontade dos agentes que atuam no Sistema. Poder este que abre a tais agentes determinadas possibilidades, mas que ao mesmo também cria poderosas restrições sobre eles. É válido clarificar aqui que a ênfase nas relações fetichistas não deve ser aqui pensada como uma afirmação da "ignorância" dos diferentes atores diante da lógica do capital, mas sim de compreender como o capitalismo suscita processos objetivos que compelem os indivíduos a agirem subjetivamente de

próprio Wallerstein, permite melhor situar esse ponto: “nos sistemas pré-capitalistas, a acumulação de capital como fim em si está em segundo plano, face a outras considerações político-sociais. A caraterística de um sistema capitalista é que esse sistema recompensa a acumulação como fim em si e elimina grupos individuais que resistem a essa lógica" (WALLERSTEIN, 1979, p. 276 apud VIEIRA, 2012, p. 166). 
determinadas formas e não de outras. Em segundo lugar, as formulações feitas até agora nos permitem desde já avançar aqui uma hipótese deste trabalho: muitos dos aspectos disruptivos, irracionais e incontroláveis que caracterizam a dinâmica sistêmica na contemporaneidade podem ser melhor iluminados com um olhar que priorize os dispositivos fetichistas do capitalismo, sobretudo quando este último se encontra em crise. Por fim, antes de entrarmos no debate com Arrighi, Fiori e Wallerstein, na próxima seção discutiremos brevemente a contribuição de Fernand Braudel. Isso se justifica porque a visão de capitalismo do historiador francês é uma influência importante para os autores com os quais debateremos.

\section{1) O "edifício" de Braudel e suas lacunas}

A leitura de Braudel do capitalismo histórico chama atenção para a continuidade na longa duração de hierarquias (Braudel, 1987, p. 43). Na sua famosa metáfora do "edifício" de três andares (ibidem, p.91) haveria um andar de baixo - a chamada vida material - cuja finalidade seria a mera reprodução da vida através da produção de valores de uso. Acima da vida material estaria o andar do meio que seria a economia de mercado. Nele, predominariam as práticas efetivamente concorrenciais, o "preço justo", a luta impessoal de todos contra todos e a extrema especialização produtiva. Tal economia de mercado jamais poderia ser confundida com o que Braudel efetivamente chama de capitalismo, o "andar de cima". Assim, no topo do "edifício", a negação da concorrência - isto é, o monopólio - seria a regra. Tampouco existiria o "preço justo", mas sim diferentes formas de se garantir de forma perene os lucros extraordinários. Logo, o capitalismo seria melhor descrito como uma espécie de "antimercado" ao contrário das definições convencionais. Ao mesmo tempo, os capitalistas jamais ficariam restritos a uma única atividade específica tal como os agentes da economia de mercado. A flexibilidade e capacidade de mudança seriam os atributos daqueles que estariam no topo da hierarquia. Deste modo, Braudel negava uma definição de capitalismo que englobasse num mesmo conceito, por exemplo, um Warren Buffet e o dono de um pequeno comércio - este sim subordinado à lógica "cega" da concorrência. "O capitalismo deriva, por excelência, das atividades econômicas desenvolvidas na cúpula ou que tendem para a cúpula." (Ibidem, p. 91). E, na sua definição do conceito, o Estado ocupará lugar central. Pois não há outra forma de se garantir a permanência no longo prazo dos privilégios monopolistas sem seu apoio. "O capitalismo só triunfa quando se identifica com o Estado, quando ele é o Estado." (Ibidem, p.55).

Note-se que para Braudel é essa articulação no topo do "edifício" que unifica a Economia-Mundo". (Ibidem, p. 68) Pois é apenas a partir do "andar de cima" onde capital e

(4) Braudel usa o conceito de Economia-Mundo e não Sistema-Mundo como Wallerstein. A diferença é que no primeiro caso trata-se de uma estrutura que busca a abarcar a totalidade da vida social sem fazê-lo de forma acabada, enquanto que no 
Estado estão fundidos que serão soldados os elos que unificam as regiões outrora apartadas. A Europa será então o lócus que irradia o processo na medida em que sua história específica de disputas entre soberanias nacionais há de reforçar a fusão entre poder e capital que depois há de se espraiar para fora do continente. Muito mais que a suposta capacidade de inovação ou espírito empreendedor dos europeus, será precisamente tal conurbação entre poder e capital sempre mediada pela violência - que projetará o capitalismo ao resto do mundo em busca de lucros monopolistas. Assim como o "andar" capitalista submete os demais "andares" do "edifício" braudeliano numa mesma região, dentro da Economia-Mundo também haverá a predominância dos capitalistas de uma região dominante em relação ao "edifício" de outras regiões. Historicamente, a sucessão de polos dominantes iniciou-se nas cidades italianas no século XIII, passando por Holanda, Inglaterra, até chegar aos EUA. Todo esse período Braudel chamará de capitalismo, evitando outras periodizações que apontam, por exemplo, a Revolução Industrial como um marco decisivo para o seu advento. Pois, para ele, o mais importante para a compreensão do capitalismo será entender como se dá na longa duração um determinado jogo sempre liderado pelo "andar de cima".

Certamente a visão de Braudel tem méritos ao acentuar na história a continuada reprodução de privilégios em torno de uma cúpula que se adapta a diversas conformações sociais. Não obstante, a sua metáfora do capitalismo como um "edifício" apresenta lacunas importantes que comentaremos a seguir. Mais precisamente, não se trata de nos contrapormos à sua obra em si, cujo escopo inclusive não vai além do século XVIII, mas sim problematizar questões que emanam da sua definição de capitalismo e que de formas distintas aparecerão nas abordagens sistêmicas contemporâneas que debatermos na próxima seção. A forma pela qual a definição de Braudel separa e justapõe os três "andares" nos parece questionável, posto que a construção de seu "edifício" deixa de lado elementos cruciais da dinâmica capitalista. Mais concretamente, ao se fundamentar o capitalismo como o amálgama entre poder e riqueza dos estratos superiores da sociedade, perde-se de vista que a lógica de imposição do capital traz consigo um processo que abarca e revoluciona a dinâmica da produção e dos mercados num dado sentido. Na medida em que a acumulação de capital como fim em si ganha corpo, a vida material e os mercados passam a ser ressignificados e reconfigurados pelo próprio processo capitalista e não guardam meramente uma relação exterior com este último, tornando assim problemática a divisão tripartite presente na formulação de Braudel. De forma análoga, vale comentar aqui que é justamente a compartimentalização realizada por Braudel o que fundamenta a sua noção de que o Capitalismo, ao lidar diretamente com a produção, se sentiria desconfortável e rigidamente preso, ou seja "fora de casa", ao passo que ele estaria "dentro de casa", isto é, à vontade, ao se embrenhar de forma flexível pelas finanças e pela circulação sem contato direto com os empreendimentos efetivamente produtivos (Braudel, 1995, Vol.3, p.327329). O problema aqui deste enfoque é que ele oblitera o caráter processual do capitalismo em

segundo tal totalidade já se coloca como objeto de análise posto. “(...)em Braudel a economia-mundo é uma estrutura entrelaçada a outras e que tende a se lhes sobrepor, no sentido totalizante já discutido, em Wallerstein, essa mesma economia-mundo constituise como totalidade já consumada, como fundamento estrutural do sistema-mundo moderno." Vieira (2012, p. 150) 
que produção, comercialização e finanças fazem parte do mesmo movimento incessante de valorização.

O dito acima nos remete ao lugar que os dispositivos pessoais de dominação ocupam na formulação braudeliana. Os laços privilegiados, a destreza, os arranjos flexíveis e os interesses das cúpulas sociais tendem a aparecer como os fatores decisivos a moldar e direcionar o evolver da Economia-Mundo através de suas conexões e de sua influência junto aos Estados. O risco que se corre aqui é o de se hipertrofiar o arbítrio dos indivíduos que ocupam o topo das hierarquias e que se apropriam dos monopólios sociais. Pois mesmo que seja certamente válida a ideia de Braudel de que o Capitalismo na longa duração é marcado pela continuada reprodução de privilégios pessoais para seu "andar de cima", há que se considerar também que há um conjunto de aspectos de sua dinâmica que podem ser melhor descortinados a partir da apreensão dos dispositivos de dominação impessoal do capital que compelem a vida social para determinadas direções. Tais considerações não anulam o fato de que justamente uma das maiores contribuições da obra de Braudel seja a apreensão das estruturas de longo prazo em que as transformações são lentas e que, portanto, o papel dos indivíduos torna-se extremamente diluído. A diferença de acento tônico aqui proposta não reside na noção muito profícua de Braudel de que a história comporta ritmos diferenciados de mudança social. (Vieira, 2012, p. 59-63) A diferença reside sim no fato de que sua definição aponta para uma dinâmica capitalista em que os nexos da realidade se alicerçam a partir do jogo de poder e riqueza determinadas "do alto", enquanto salientamos de nossa parte o fato de que esta mesma dinâmica produz nexos a partir de uma força objetivada e alienada que crescentemente conforma e dá sentido às diferentes esferas e "andares" da vida social.

\section{2) Capitalismo contemporâneo e as abordagens sistêmicas}

\section{a) Arrighi:}

Influenciado por Braudel, Giovanni Arrighi irá desenvolver sua análise dos Ciclos Sistêmicos de Acumulação com o objetivo de apreender os momentos de ruptura que levam às trocas de hegemonia no interior do Sistema-Mundo. Marcados por duas fases, os Ciclos Sistêmicos teriam um primeiro momento de expansão material que seria seguido depois por uma expansão financeira (ARRIGHI, 1996, p.6). No primeiro caso, um determinado polo lideraria e pavimentaria o caminho para expansão da produção e do comércio através de inovações e mudanças nas formas de se empreender. O capital estaria embrenhado em investimentos mais "rígidos", mas que no entanto se justificariam pela sua maior rentabilidade. Porém, tal expansão material não poderia ser perene pois inevitavelmente a própria 
concorrência entre as regiões do Sistema suscitaria crises de superacumulação e queda dos lucros. A expansão financeira que daí seria decorrente, assentada no acúmulo de recursos da fase anterior de expansão material, seria o momento em que o capital lograria diversificar seus investimentos rumo a aplicações mais "líquidas" e "flexíveis". Mas se a expansão finnanceira aparece como válvula de escape para o declínio de rentabilidade produtiva e comercial, ela também traz consigo sinais do canto de cisne de uma dada hegemonia. A partir daí, um novo lócus lideraria uma retomada do processo de expansão material e paulatinamente destronaria o antigo polo dominante. Destarte, a despeito do fato de que cada hegemonia seja mais abrangente e complexa no seu arranjo, seria possível ler no capitalismo uma dinâmica cíclica em que uma dada cúpula ascende para depois entrar em crise e perder sua liderança. ${ }^{5}$ Daí que no enfoque de Arrighi (Ibidem, XII) "os ciclos sistêmicos de acumulação são processos ligados ao 'alto comando' da economia capitalista mundial, o 'verdadeiro lar do capitalismo', segundo Braudel".

Tal construção de Arrighi é o ponto de partida de sua reflexão sobre o capitalismo contemporâneo. Tal como nos anteriores, o Ciclo Sistêmico liderado pelos EUA, cuja expansão material teria se dado no pós-guerra, deu lugar a uma fase de expansão financeira. Mas haveria aqui algo novo. A Ásia Oriental, sob liderança chinesa, passava a ser o centro de uma nova expansão material mundial. Já os EUA, mesmo debilitados economicamente e endividados em boa parte com a própria Ásia, se mantinham como potência militar mundial inconteste. Tal cenário seria algo inédito no capitalismo, a saber, a bifurcação entre poder político/militar e poder econômico. Afinal, o poder econômico da China não estaria sendo suportado por sua força político/militar. O ineditismo de tal separação criava um quadro de insustentabilidade sistêmica que exigia alguma solução. Esta solução poderia simplesmente ser o caos. Mas, por outro lado, poderia estar em curso o advento de uma nova ordem marcada pela formação de uma "sociedade de mercado mundial" centrada na China (Arrighi, 2008, p.22-24). Discutiremos aqui esta última hipótese, não apenas pela sua originalidade, mas principalmente porque através dela é possível traçar um cenário mais amplo dos dilemas atuais do SistemaMundo.

Para sustentar seu argumento, Arrighi mobiliza a sociologia histórica de Adam Smith e o aporte braudeliano, traçando um rico quadro comparativo entre a Europa e a China Imperial. No caso europeu - que depois se desdobraria no padrão estadunidense do século XX - a fusão entre Estado e capital induziu ao expansionismo, ao militarismo e ao controle dos mercados pelo alto de forma monopolista e exclusivista. Já na China, mesmo que tais processos não estivessem de todo ausentes, houve a prevalência de uma dinâmica informada pelo "andar do meio" de Braudel ${ }^{6}$ a saber, uma dinâmica efetivamente assentada em inúmeros mercados locais e na concorrência generalizada que fez com que a economia chinesa fosse inclusive até o início

(5) Arrighi (1996, p.37) discute os ciclos na história do capitalismo a partir dos mesmos quatro polos hegemônicos que já citamos acima com Braudel.

(6) Arrighi (Ibidem, p. 338) "O próprio Braudel adota a China Imperial como o exemplo que 'mais oportunamente sustenta [sua] insistência em separar a economia de mercado de capitalismo "” 
do século XIX maior que a europeia. Ao mesmo tempo, longe de configurar um padrão de "mercados autorregulados", o modelo chinês de desenvolvimento esteve sempre inserido em instituições ${ }^{7}$ sociais, culturais e políticas que visavam conduzir a lógica concorrencial dos mercados para a integração social e nacional (Ibidem, p. 63).

Tais assertivas fazem que Arrighi considere o padrão histórico europeu como capitalista e o chinês como não capitalista (Ibidem, p. 339). E neste século XXI, a China trazia ainda consigo elementos deste padrão que poderiam ser fonte de uma nova ordem internacional. Uma ordem muito mais assentada na capacidade de concorrência econômica em mercados e inserida em instituições reguladoras da vida social. Recuperando uma perspectiva aventada já por Smith, a China poderia liderar, portanto, uma efetiva "sociedade de mercado mundial" (Arrighi, 2010, p.15) em que a tradicional capacidade do país de enquadrar uma intensa concorrência mercantil dentro de determinados objetivos sociais maiores ${ }^{8}$ poderia conformar um mundo mais harmonioso e pacífico e menos assimétrico. ${ }^{9}$ Isto significaria o fim ou pelo menos o enfraquecimento do capitalismo no sentido de Braudel, com sua reprodução de privilégios assentados na trinca poder-riqueza-violência (Arrighi, 1996, p. 372). Por certo a consolidação de tal cenário não estaria garantida de antemão. Em primeiro lugar ainda caberia à China superar as suas próprias contradições internas para que ela inspirasse globalmente um padrão de desenvolvimento mais equilibrado e uma relação mais sadia entre economia e sociedade (Arrighi, 2008, p.357-393). Em segundo lugar, as continuadas pressões político/militares dos EUA poderiam perfeitamente atuar no sentido de bloquear as transformações acarretadas pela subida da China. "Se o sistema entrar em colapso, será sobretudo pela resistência norte-americana à adaptação e conciliação" (Arrighi, 2001, p.287). A combinação entre os fracassos internos da própria China e a inflexibilidade dos EUA poderia jogar o mundo no caos.

Mesmo considerando sua retórica cuidadosa, até que ponto a formulação engenhosa de Arrighi se sustenta? Antes de voltarmos à sua hipótese da "sociedade de mercado mundial" cabe uma contextualização. Num texto escrito em 2009, pouco antes de falecer, Arrighi (2010, p. 1) escreve "a expansão financeira (...) nas últimas décadas do século XX não foi um fenômeno novo mas uma tendência recorrente do capitalismo histórico. Se o passado tem valia para o presente e futuro, poderíamos esperar que a expansão financeira iria restaurar

(7) Para Arrighi (Ibidem, p. 59), ao contrário de certas visões equivocadas, Smith pensava que "o uso do mercado pelo governo(...) tinha não só propósitos sociais como também estava sujeito a fortes restrições sociais". Daí o fato de que para Arrighi o modelo chinês de desenvolvimento fosse bem visto para Smith.

(8) Aqui ele sintetiza "Se essa reorientação conseguir reviver e consolidar as tradições chinesas de desenvolvimento baseado no mercado e centrado em si mesmo, de acumulação sem desapropriação, de mobilização de recursos humanos, ao invés de não-humanos, e de governo com participação das massas na configuração das políticas, então existe a possibilidade de que a China esteja em posição de contribuir decisivamente para o surgimento de uma comunidade de civilizações que de fato respeite as diferenças culturais." (Arrighi, 2008, p. 393).

(9) Nas suas palavras, “A tese geral apresentada neste livro é que o fracasso do Projeto para o Novo Século NorteAmericano e o sucesso do desenvolvimento econômico chinês, tomados em conjunto, tornaram mais provável do que nunca (...) a concretização da ideia de Smith de uma sociedade mundial de mercado baseada em uma maior igualdade entre as civilizações." (Ibidem, p. 24) 
A crise contemporânea do capitalismo: reflexões a partir de um debate com as abordagens sistêmicas...

temporariamente a fortuna(...) dos EUA, mas iria resultar numa mudança na liderança do centro de acumulação mundial em escala global." De nossa parte, sugerimos um outro ângulo de abordagem da expansão financeira das últimas décadas. Não porque pretendemos polemizar com a citação acima, inclusive porque nela a preocupação de Arrighi é refletir sobre a insustentabilidade sistêmica que já mencionamos e não sobre o estatuto da financeirização em si. No entanto, tentaremos após a contextualização que se segue, mostrar justamente uma outra forma de olhar para os dilemas sistêmicos. Senão, vejamos. A resiliência de crises recorrentes, do endividamento crescente e do componente crescentemente especulativo e curto-prazista das decisões capitalistas sugerem algo não fortuito. A já longa perenidade do processo de financeirização, tornado ele mesmo o próprio modus operandi do capitalismo, e o fato de que nem mesmo graves crises como a de 2008 acarretem na sua contenção, denotam mudanças de qualidade no capitalismo. ${ }^{10}$ A dinâmica em curso, indica, portanto, algo mais profundo e além do arbítrio da própria cúpula capitalista.

A crescente disparidade nas últimas décadas entre, de um lado, a acumulação produtiva e expansão material bloqueadas, e, de outro lado, o crescimento expandido de formas fictícias de valorização, desvelam a ausência de qualquer padrão sustentável de acumulação de capital. Fenômeno este que se liga, por sua vez, a uma queda estrutural e não meramente cíclica das taxas de lucro, ${ }^{11}$ aonde nem mesmo as crises logram recompor as condições para uma retomada perene do processo de acumulação. ${ }^{12}$ Daí que a hipertrofia financeira e o recurso desmedido ao crédito revelem uma tentativa de acelerar o tempo do capitalismo, antecipando-se o futuro através da criação de capital fictício, num quadro em que a expansão do valor encontra-se

(10) Alguns dados que parecem corroborar o dito acima. Mesmo depois da crise de 2008 o grau de endividamento dos diferentes agentes da economia continuou crescendo: "essa dívida representa(...) $286 \%$ do PIB mundial em 2014, mais do que era em 2007, 269\%, antes do estouro da crise.” (HUSSON, p.2). Em 2016, segundo o IIF, essa cifra chegaria a 325\%. (Valor, 2017). Na mesma toada, Paulani (2013, p. 255) chama atenção para "a multiplicação por três da relação entre ativos financeiros e PIB mundial, a qual salta de 1,12, em 1980, para 3,37 em 2010". No que tange ao aumento exponencial do número de crises financeiras a partir de 1970 ver Gontijo; Oliveira (2008, p.5). Sobre a dinâmica especulativa e curto-prazista do capitalismo contemporâneo e seus efeitos ver Guttman (2008).

(11) Roberts (2016, p. 224) estima uma queda na taxa de lucro dos países do G7 entre 2002 e 2011 de 20,4\%, queda esta puxada por um aumento da composição orgânica do capital de 41,3\%. Ele também traz uma estimativa de longo prazo que aponta o mesmo resultado em função da mesma causa "Nas economias do G7, a taxa de lucro caiu de forma secular entre 1950 e 2011 porque nesse período a composição orgânica de capital subiu muito mais do que a taxa de mais valia." (Ibidem, p.223). Kliman (2012, p. 130) analisando os EUA entre 1947 e 2007 chega às mesmas conclusões, imputando ao aumento da composição orgânica $89 \%$ da responsabilidade pela queda secular da lucratividade. Maito $(2014$, p. 14) elabora o que chama de uma "taxa de lucro mundial" ponderada pelos pesos relativos de 14 economias que em 2010 perfaziam 57,3\% do PIB mundial. Além de países ricos, nessa estimativa estão países periféricos como Argentina, Brasil, México e China. Seus dados sugerem que desde meados dos anos 1960 há uma queda na taxa de lucro, com leve recuperação e estabilização com o advento do neoliberalismo entre os 1980 e 1990 , e nova queda rápida a partir de 2004 aproximadamente. Por fim, Roberts indica queda na taxa de lucro nas últimas décadas em países como Brasil (ROBERTS, 2016, p. 189), Índia (Ibidem, p. 201) e mesmo a China (Ibidem, p. 213)

(12) Kliman (2015, p. 81-88) sustenta que as quedas hodiernas nas taxas de acumulação produtiva guardam estreita relação com a queda da lucratividade. 
comprometida. ${ }^{13}$ Não por outros motivos ganha relevância o debate acerca da vigência de limites internos ao próprio capital que estariam se absolutizando neste século XXI. Tais limites seriam derivados da potencialização daquilo que Marx (2012, p.12) chamou de "contradição em processo" a saber, a tendência posta pela lógica concorrencial do capital de transformar o trabalho vivo em obsoleto para a produção de riqueza material ao passo que o mesmo capital prossegue exigindo a extração de mais-trabalho como pressuposto de sua própria valorização. ${ }^{14}$ Tal travamento da expansão do valor e da mais-valia estaria ganhando corpo com os desdobramentos da Terceira e Quarta Revoluções Industriais em que a ciência e o conhecimento ganham um lugar cada vez mais proeminente nos dispositivos de produção. ${ }^{15}$ Se não temos aqui, por um lado, as condições de esmiuçar a hipótese da vigência de um limite absoluto do capital, cremos que podemos, por outro lado, assinalar como válida a noção de uma crise estrutural do capital. Crise, esta, cujos desdobramentos implicam transformações adversas no mundo do trabalho e na capacidade de integração dos indivíduos às diferentes economias, aumento das fricções nas Relações Internacionais e a acentuação da irracionalidade da dinâmica fetichista capitalista.

Traçado o quadro acima, que também será útil no diálogo com Fiori e Wallerstein, podemos retomar hipótese de Arrighi de uma "sociedade de mercado mundial" impulsionada pela China. Neste sentido, a primeira questão a ser levantada é a do próprio estatuto da recente ascensão econômica chinesa. Se as idiossincrasias e o crescimento impressionante da China são fatos indiscutíveis, outra coisa distinta é saber se isto estaria engendrando uma verdadeira expansão material sistêmica, isto é, um processo generalizado de expansão de mercados e de acumulação que se difunde por todo o Sistema. Não temos condições aqui de tratar com maior profundidade as transformações trazidas pela ascensão chinesa e de seus efeitos globais. De toda forma elencamos algumas observações. Nos parece duvidoso que uma expansão atual impulsionada pela China tenha o mesmo efeito de expansões sistêmicas anteriores, pois, se a China teve o seu "milagre" nas últimas décadas, isso não anula o fato maior de que no mesmo período o crescimento econômico e a acumulação produtiva de capital no globo têm sido tendencialmente pífios. Ademais, sem o boom ancorado em capital fictício nos EUA e outras regiões (BRENNER, 2003, p. 264) não teria sido possível um crescimento de tal magnitude liderado pelas exportações na China. Mais ainda, a própria economia chinesa após a crise de 2008 tem lançado mão de uma expansão desmedida de crédito e capital fictício para tentar retomar em vão suas taxas de crescimento de outrora (Chengsi, 2016). A excepcionalidade da

(13) Para Postone (2017, p. 51) “a financeirização agora não seria exatamente como no passado, (...) agora a expansão da economia da dívida estaria ocorrendo contra um pano de fundo de uma produção de mais-valia estagnada". Para uma formulação semelhante, ver Kliman (2015, p. 72-73).

(14) Para Marx, atingido certo ponto, "o incremento da produtividade chegaria a ser indiferente para o capital do ponto de vista de sua valorização(...) ele teria deixado de ser Capital" (MARX apud ROSDOLSKY, 2001, p. 200). O conceito de um limite absoluto do capital na contemporaneidade é trazido por Chesnais (2016, p. 264-267) a partir da reflexão sobre a referida "contradição em processo".

(15) Para Collins (2013, p. 67-68) em função dos novos dispositivos tecnológicos, mesmo empregos típicos de "classe média" nos setores de supervisão, serviços, etc., tendem a ser eliminados em larga escala. 
China não livra o país, e muito o menos o mundo, das consequências de uma crise estrutural e de longo prazo. Destarte, se a insustentabidade que Arrighi aponta a partir da bifurcação entre a força político/militar do Ocidente e a nova força econômica do Oriente é, sem dúvida, uma questão extremamente pertinente, não menos importante é indicar as consequências sistêmicas de um padrão de acumulação global igualmente insustentável. ${ }^{16}$ Visto por essa ótica, o advento da "sociedade de mercado mundial" e suas consequências benéficas tornam-se, portanto, mais remotos. ${ }^{17}$

Ao mesmo tempo, é pouco provável que a ascensão sino-asiática produza uma tal dinâmica que venha a mitigar de forma significativa o jogo secular de força no Sistema. Pois mesmo que o deslocamento do centro econômico para o Oriente tornasse as lutas nacionais menos disruptivas, ainda restaria um outro problema, a saber, a necessidade de um dispositivo político que tente assentar as condições de reprodução de um capitalismo cada vez mais internacionalizado. Neste sentido, como bem mostrou Wood (2014, p. 109-125) o caráter do imperialismo no século XXI - caracterizado por "guerras sem fim e sem objetivo claro" - tem fundamentalmente a ver com a necessidade de se produzir alguma ordem para um capitalismo cada vez mais global em meio à miríade de soberanias nacionais conflitantes entre si. Para uma economia cada vez mais transnacionalmente integrada não há uma estrutura política transnacional correspondente. Precisamente desta contradição emana uma tendência ao caos e também o caráter cada vez mais de "polícia mundial" do imperialismo dos EUA, pelo lugar que ocupam no mundo. Por isso, o importante para os EUA não seria tanto como no passado a contenção de um inimigo claro e definido, mas sim o efeito demonstração sobre o conjunto de Estados Nacionais através do combate a inimigos difusos como o terrorismo. Mais do que efetivamente derrotar o terror, a questão-chave seria a de explorar a opacidade de adversários a serem combatidos ad eternum para exibir força. Em suma, o militarismo inflado dos EUA, mesmo que não deixe de corresponder a interesses diretamente norte-americanos, refletiria a necessidade de se buscar algum ordenamento político-sistêmico na base da coação do conjunto das nações. Assim, se o belicismo contemporâneo não depende apenas da existência de conflitos nacionais diretos entre países, mas também ganha vigor com o próprio potencial de anarquia política mundial, há de se perguntar como a hipotética nova dinâmica trazida do Oriente poderia reduzir a importância da violência em escala global.

Ademais, num plano mais geral, o fim do capitalismo no sentido de Arrighi e Braudel não pode entregar o que promete. Em si mesmo, tal hipotético processo deixaria intacta a

(16) Alguém poderia contra-argumentar aqui que a criação em massa de empregos na China desde os anos 1980 contradiz em parte as tendências aqui descritas. Como vimos em nota acima, Arrighi acentua este aspecto ao considerar que o modelo chinês estaria assentado na "mobilização de recursos humanos, ao invés de não-humanos". Sem ter a pretensão de esgotar o tema, pensamos que é preciso balizar tal afirmação de Arrighi. Por exemplo, a China está virando o país com mais robôs no mundo e nos últimos três anos há de forma inédita uma redução do número de trabalhadores na sua manufatura, fatores que permitem antever problemas de empregabilidade no país. Financial Times (2017).

(17) Há de se considerar aqui também os efeitos das transformações capitalistas para toda a Periferia do Sistema além da China. Faremos esse debate de forma mais detida na próxima subseção. De toda forma, podemos adiantar aqui que tais efeitos trazem novos contornos que vão na contramão da hipótese de Arrighi de uma "maior igualdade entre as civilizações". 
relação de capital que não se resume nem aos privilégios da cúpula braudeliana e nem à concorrência em mercados, mas que implica todo um modo de reprodução da vida. Deste modo, não se poderia conter a dinâmica irracional e disruptiva que acompanha a própria lógica do capital sobretudo quando esta encontra-se em crise. Afinal a violência que marca toda a história do Sistema Mundo não é produto apenas das disputas hegemônicas entre os Estados, mas também faz parte do próprio processo tumultuoso de imposição da socialização capitalista. E, num cenário de crise, tal violência tende a se intensificar, assim como o nacionalismo xenófobo e o potencial de distúrbios nas relações internacionais. Neste aspecto também a possibilidade de institucionalização benfazeja da "sociedade de mercado mundial" encontra barreiras.

\section{b) Fiori}

Se José Luís Fiori também é influenciado pela definição braudeliana de capitalismo, sua visão sistêmica é bem diferente da de Arrighi. Para o autor brasileiro, Arrighi preconiza erradamente a queda da hegemonia dos EUA justamente por lhe faltar uma perspectiva de longo prazo braudeliana (Fiori, 2008, p. 18-20). Nesta última, para Fiori, o poder americano teria se reforçado a partir dos anos 1970. Por exemplo, a derrota no Vietnã foi seguida da aproximação de Nixon com Mao, o que ajudou a debelar a ameaça soviética. E, com a queda posterior da URSS, os EUA se sacramentariam como potência militar inalcançável. No plano econômico, a perda relativa de competitividade americana no início dos 1970 e a conjuntura que levou ao fim dos acordos de Bretton Woods pavimentou o caminho - reforçado pela política Volcker de 1979 - da predominância inconteste do dólar como moeda reserva e todos os privilégios daí advindos, inclusive os militares. Assim, a financeirização centrada nos EUA não significaria enfraquecimento, mas sim o seu oposto.

Mas mais que reafirmar a força dos EUA, Fiori oferece uma teorização própria da história do Sistema Interestatal Capitalista ${ }^{18}$ em contraposição a Arrighi e Wallerstein. Haveria uma tendência destes autores enfatizarem as "contribuições positivas do poder hegemônico para o funcionamento do sistema, (...) Por isso (...) estas teorias chamam de crise qualquer

(18) Fiori (2014, p.17) usa o termo Sistema Interestatal Capitalista para afirmar “a importância permanente e insuperável dos Estados Nacionais". Ao mesmo tempo, cabe frisar que Fiori não deve ser enquadrado na perspectiva do Sistema-Mundo tal qual Arrighi e Wallerstein. Para além da ênfase maior de Fiori na esfera política, a diferença de fundo parece estar situada na seguinte questão: Na perspectiva do Sistema-Mundo - em especial em Wallerstein - o Sistema é uma totalidade espaço-temporal cujo movimento é dado sempre pelo conjunto. Daí a ideia de que o Sistema conforme um dado "Mundo" que unifica na mesma temporalidade suas diferentes partes. Já Fiori parece estar inspirado na reformulação proposta por Norbert Elias para as ciências sociais. Buscando superar o que pensava ser uma falsa dicotomia entre o individualismo metodológico e as visões mais holísticas, Elias sugeria uma abordagem que enfatizasse o caráter interativo e relacional da vida social. Transposto para o plano sistêmico, isso significa para Fiori colocar o acento tônico nos constantes choques e interações entre Estados e economias nacionais conformando a sua metáfora de "Universo em Expansão" que comentaremos a seguir. Sobre estes temas, ver Mariutti (2012, 2012b) 
disfunção sistêmica e anunciam crises terminais." (Fiori, 2008, p. 21) Em contrapartida, Fiori avança o seu conceito de "Universo em expansão". A dinâmica iniciada na Europa no século XIII ao generalizar a busca por acumulação não apenas de capital, mas também de poder político, seria por sua própria natureza incessante e caótica. A pressão competitiva no interior do "Universo" tenderia portanto a "um aumento do número e da intensidade dos conflitos" (Ibidem, p. 17). Logo, a desordem do Sistema seria o pressuposto do contínuo movimento do seu "Universo em Expansão". Como sugere Norbert Elias, 1976 (apud Fiori 2005, p. 61) "a mera preservação da existência social exige(...)uma expansão constante. Quem não sobe, cai". Assim, os momentos de instabilidade para Fiori jamais podem indicar per se uma crise hegemônica e menos ainda uma crise sistêmica. Pois são exatamente os momentos de intensificação de disputas - os quais Fiori chama de "explosões expansivas" - que farão o Sistema ampliar ainda mais e que também abrirão espaço para que a potência-líder busque incrementar o seu poderio (Fiori, 2008, p. 22). Assim, tal como nos anos 1970, neste século XXI uma nova "explosão expansiva" estaria em processo movida pela "estratégia expansionista e imperial dos EUA, mas também pela multiplicação dos Estados soberanos do Sistema, que já são cerca de duzentos, e finalmente, pelo crescimento vertiginoso do poder e riqueza dos estados asiáticos, e da China em particular (Ibidem, p. 24). Tal cenário para Fiori tende a intensificar o nacionalismo econômico (Ibidem, p. 66) e também permite prever "uma nova corrida imperialista e uma gigantesca expansão das fronteiras deste universo mundial" (Ibidem, p. 24). E mais uma vez, à despeito das fragilidades conjunturais, tudo indicava no longo prazo que um enfraquecimento substantivo dos EUA seria um mito.

Fiori tem o mérito de salientar o caráter de tensão permanente e desordem no Sistema. Mas, por outro lado, uma questão que pode ser levantada é a seguinte: "Universo em Expansão", mas expansão até onde? Nos marcos de sua reflexão "a energia que move esse sistema vem da luta e da competição entre seus Estados e economias nacionais, pela conquista de posições monopólios, escassas e desiguais, por definição”. (Ibidem, p. 27)." Com isto se institui um processo infinito e ascendente que projeta sempre para frente o Sistema (Fiori, 2014, p. 31). Mas justamente o que indagamos é até que ponto tal construção ajuda a explicar a dinâmica recente do capitalismo. Não seria mais correto dizer que este mesmo "Universo" estaria hoje vivendo numa fase de estagnação ou mesmo de retração? Se o processo de acumulação de capital encontra obstáculos não meramente episódicos, mas sim estruturais, a ideia de uma eterna expansividade sistêmica fica prejudicada. Consequentemente, nos parece que os conflitos e a desordem global que marcam o século XXI não podem ser lidas adequadamente na perspectiva de mais uma nova "explosão expansiva". Em outras palavras, sem desconsiderar as lutas interestatais por poder e riqueza que Fiori analisa com argúcia, é preciso situar a instabilidade presente nas relações internacionais na própria ordem capitalista em crise. A nosso ver o problema maior da formulação de Fiori reside na sua noção de que o Sistema teria como impulso primordial a lógica da acumulação de poder como fim em si, isto é, uma dinâmica de "poder pelo poder". Tal enfoque tende a projetar no presente um viés politicista que erige como principais sujeitos da dinâmica capitalista os próprios Estados em 
sua eterna e crescente busca pela incorporação de força. Oblitera-se, assim, o papel de sujeito do próprio capital que com sua lógica tautológica e suas imposições informa os meandros da vida política e social. Ao afirmar que "a única certeza é que o sistema deverá encontrar novos espaços e territórios de expansão (...) movido pela mesma energia fundamental empregada em suas competições e guerras internas" (Ibidem, p.32), Fiori elide a vigência de limites tanto ao capital como ao próprio Sistema.

Tais considerações suscitam uma leitura distinta do estatuto atual do poder americano. Fiori por certo tem razão em destacar a força ímpar do dólar e os atributos exclusivos de senhoriagem dos EUA que reforçam seu poder político e militar. Além disso, os EUA podem também insuflar booms econômicos artificiais como o da década passada e se dar ao luxo de enormes déficits público e comercial. Mas isto não anula o fato de que os EUA sejam o epicentro de um padrão global de acumulação cada vez mais instável, amparado na financeirização e expansão desmedida de crédito, com consequências adversas consideráveis. Destarte, as bases do capitalismo - nos EUA e no mundo - passam a depender, a nosso ver, de uma dinâmica cada vez mais irracional e fetichista através da criação desmedida de capital fictício. Os limites de tal ficcionalização, explicitados na crise do subprime, são evidentes e nada aponta para um novo padrão de acumulação que os transcenda. Neste sentido os privilégios econômicos dos EUA andam pari-passu com um processo de fragilidade econômica global do qual eles são os próprios pivôs. ${ }^{19}$

Destarte, se na origem a liderança dos EUA pôde se projetar no quadro de um capitalismo mundial em franco e perene crescimento, não se pode dizer o mesmo num presente marcado por crises em maior quantidade e profundidade, baixo crescimento, desmantelamento das redes de proteção social e piora crescente na distribuição de renda. Tal cenário amplifica as dificuldades para a integração dos indivíduos às diferentes economias e mina a coesão social de forma generalizada. Se os anos 1990 puderam suscitar ainda um conjunto de ilusões em torno de uma próspera liberalização econômica mundial liderada pelos EUA, no século XXI cresce a sensação de mal-estar com a assim chamada globalização. (Streeck, 2016). Assim, mesmo que tenha à sua disposição um poderio militar inaudito, isso não isenta os EUA de exercerem um papel de liderança em meio a um quadro que não autoriza expectativas de prosperidade e ascensão social e que, portanto, tende a ser mais conflitivo. A intensificação do nacionalismo ${ }^{20}$ de cariz xenófobo é talvez o fenômeno mais marcante de tais turbulências. Isso suscita problemas de legitimação política tanto dentro dos EUA como também para a sua liderança global. Neste sentido, a trama política no interior no Sistema se defronta com imperativos sociais e econômicos oriundos das vicissitudes de um capitalismo em crise que desabonam, a nosso ver, a ideia de uma agregação sem limites de poder, seja ela capitaneada pelos EUA ou não.

(19) Vale frisar ainda que mesmo que não esteja à vista até agora um questionamento do dólar, este cenário não é de todo descartável. Para uma discussão do tema ver Eichengreen (2011, p. 151-172)

(20) Hobsbawm (2007, p.86-96) anteviu essa tendência de forma percuciente. 
Um desdobramento importante desta discussão parte das mudanças no estatuto de regiões e países do que se convencionou chamar de Periferia do Sistema. Se, no passado, o próprio conceito de subdesenvolvimento - mesmo de forma limitada ou inclusive ilusória indicava a promessa de se alcançar padrões de consumo e produtividade do Centro e assim se atingir o estágio dos países "avançados", agora trata-se de lidar com uma tendência ao colapso do processo de modernização de muitos dos países "atrasados". Com esta última noção, pretendemos sinalizar uma mudança de qualidade que diferencia as antigas expectativas depositadas nos processos de modernização periférica do pós-guerra apoiados no Estado, com a situação efetiva que se desdobra com a dinâmica atual de crise estrutural do capital. De um lado, o curto-prazismo da financeirização solapa o planejamento de longo prazo. Os requisitos em termos de ciência, qualificação, capitalização e infraestrutura tornam-se muito grandes sobretudo para quem chegou tarde na corrida, ao passo que as mudanças tecnológicas implicam baixa incorporação de mão de obra tornando até o "dumping social" de outrora obsoleto (Kurz, 1993, p.170). Assim, a "contradição em processo" do capital tende a reforçar assimetrias e disparidades, inclusive porque as novas técnicas são monopolizadas em certos polos. ${ }^{21}$ Tudo isso tende a sinalizar o esgotamento da modernização e das perspectivas de desenvolvimento para muitos países. ${ }^{22}$ Evidentemente, tal processo não é homogêneo ${ }^{23}$ Mas isso não dilui o fato de que na Periferia a incapacidade de concorrência global de vários setores acarrete em processos de desindustrialização e desestruturação produtiva. E o mais importante é que tal tendência ao colapso da modernização, mesmo que em níveis diferenciados, tende a produzir um exército de "sujeitos monetários sem dinheiro" isto é, uma enorme quantidade de seres humanos que se tornam permanentemente supérfluos. Em casos mais extremos, como em partes da África, são regiões inteiras que se tornam literalmente excluídas dos circuitos de produção e consumo globais, intensificando-se a desagregação social e política (SCHOLZ, 2016).

É forçoso constatar que os processos acima descritos jogam mais lenha no potencial de perturbações e caos no interior do Sistema. Isso nos permite voltar a abordar o papel dos EUA e com ele o tema do imperialismo de forma mais geral. Para tanto, nos apropriamos do conceito de Kurz (2015, p. 39-51), de "Imperialismo de Crise". Este último busca cotejar as tentativas de disciplina sistêmica da parte dos EUA salientadas por Wood, mas adendando os desdobramentos da crise capitalista nas suas diferentes facetas. Assim, Kurz chama atenção para as tensões que justificam da parte dos EUA o seu militarismo e suas coerções, em especial

(21) Os dados internacionais sobre solicitações anuais de patentes ajudam a ilustrar o problema. É verdade de um lado que a China e com ela a Ásia tem tido um crescimento em sua participação mundial neste campo. Mas para a América Latina e África, suas porcentagens mundiais já exíguas vigentes em 2006 (3,0\% e 0,7\%) respectivamente, caíram ainda mais em 2016 $(2,0 \%$ e $0,7 \%)$ respectivamente (WIPO, 2017, p. 31)

(22) Mesmo que discutindo o caso brasileiro, o ensaio de Oliveira (2003, p. 125-150) é útil para uma discussão mais geral de como os próprios termos do subdesenvolvimento do pós-guerra foram alteradas dos anos 1990 para frente. Sobre a ideia de uma tendência ao colapso da modernização periférica, uma referência essencial é Kurz (1993, p. 165-197). Para uma atualização da análise de Kurz acerca do fracasso da modernização da Periferia ver Scholz (2016)

(23) O caso chinês sempre pode ser levantado como contraexemplo, mas isso não elimina o fato de que ele se assenta em condições bem particulares e dificilmente generalizáveis. 
após o 11 de setembro. Tensões que se multiplicam com populações crescentemente supérfluas para a lógica do capital, levas de imigrantes e refugiados e o desmantelamento de Estados Nacionais. ${ }^{24}$ Mas para além especificamente de tais regiões em desagregação, a ideia de um "Imperialismo de Crise" é útil também para acentuar a contradição entre a busca de algum tipo de disciplina sistêmica da parte dos EUA e um quadro global de distúrbios e ingovernabilidade crescentes. Daí que a única coisa certa é que na medida em que a crise estrutural do capitalismo reduz as margens de manobra, aumenta o potencial sistêmico de violência e, com ele, o caráter policialesco do imperialismo americano, independentemente do governo de plantão. Dado o potencial anárquico em curso, vale o argumento de Fiori de que trata-se de buscar constituir uma dada "ordem" produzindo-se mais "desordem". Mas o ponto aqui é que tal desordem não abona a expansão ilimitada sugerida por ele. Para reforçar este ponto, é válido adendar à noção de um "Imperialismo de Crise" o conceito de "acumulação por espoliação" de Harvey (2010, p. 107-111). Tal conceito põe em tela o fato do capitalismo contemporâneo ser dominado por mecanismos de expropriação de valor como privatizações, processos predatórios baseados em aquisições baratas de empresas e especulação financeira, exploração de patentes, açambarcamento de recursos naturais, etc., mecanismos estes que por sua vez reforçam os dispositivos imperialistas de violência direta ou indireta. Tal dinâmica, que meramente redistribui a riqueza existente, mesmo se nunca esteve ausente na história do capitalismo, se intensifica precisamente em consequência das barreiras à acumulação produtiva e não de uma "gigantesca expansão das fronteiras deste universo mundial".

Em síntese, o cerne dos problemas que emanam da elaboração de Fiori reside em sua visão que superestima a esfera política. ${ }^{25}$ A luta interestatal que Fiori resgata em Braudel, mesmo que seja elucidativa para a apreensão das origens e para certas dinâmicas do Sistema, acaba por ser alçada como motor de um processo que ela explica apenas de forma limitada. Daí que ele chegue a conclusões discutíveis ao afirmar que "O caminho dos 'ganhadores' está aberto a todos os países? Sim, está aberto, mas poucos serão os vencedores" (Fiori, 2014, p.45). Discordamos, porque, se assim fosse, o que faltaria aos países "derrotados" seria apenas a destreza política para fazê-los vingar, importando menos portanto todos os outros condicionantes que produzem assimetrias no interior do Sistema. Deste modo, por conceber a dinâmica internacional como um jogo progressivo sempre em aberto e também por dissociar o Sistema das vicissitudes da crise estrutural do capitalismo que ele nega a existência, a teorização de Fiori encontra limites.

\section{c) Wallerstein}

(24) Visto por este ângulo, mais do que a formação de novos Estados salientada por Fiori, o fato distintivo a ser considerado é o aumento do número de "Estados Falidos" em regiões da África e no Oriente Médio, em que a própria noção de soberania sobre seus territórios está em questão. Ver Hobsbawm (2007, p. 87)

(25) Neste sentido, o seu uso do conceito de Sistema Interestatal Capitalista é coerente com a sua exposição, mas justamente porque ele elide outras determinações importantes que se fazem presentes na perspectiva do Sistema-Mundo. Ver Mariutti (2012b, p.12) 
Uma boa forma de introduzir a contribuição de Immanuel Wallerstein para o tema em tela é resgatar uma citação sua já mencionada em outro contexto. "A caraterística de um sistema capitalista é que esse sistema recompensa a acumulação como fim em si e elimina grupos individuais que resistem a essa lógica." (Wallerstein, 1979, p. 276 apud Vieira, 2012, p. 166). Ao mesmo tempo, vale frisar aqui que essa tendência do capital em dirimir as resistências ao seu domínio não é absoluta para o autor. Isto quer dizer que o movimento de expansão do capital tende a criar barreiras e resistências para si mesmo. Ou melhor dizendo, Wallerstein se pauta numa certa dialética entre a tendência expansiva do capital e as contratendências que a minam. Todavia, para Wallerstein, no século XXI, o fator preponderante seria justamente a intensificação dos limites ao capital. A expressão concreta disso seria uma queda perene na lucratividade sinalizando uma crise terminal do SistemaMundo.

Para melhor vislumbrarmos a questão, cabe partirmos da sua apreensão da relação Centro-Periferia (Wallerstein, 2005, p. 26). Com ela, Wallerstein fundamenta os mecanismos de transferência de valor de determinadas regiões subordinadas para os polos dominantes do Sistema. Como em Braudel (Ibidem, p.16), tais mecanismos, presentes em todas as épocas do capitalismo histórico, são tanto extraeconômicos - como por exemplo o controle de determinadas rotas comerciais ou as relações diretamente coloniais com a periferia - como também diretamente econômicos e típicos do capitalismo industrial já desenvolvido quando desníveis de produtividade garantem a manutenção das trocas desiguais (Wallerstein, 2001, p. 29). Tais condições monopolísticas alargam, portanto, o excedente do Centro, ao passo que restringem a capacidade de acumulação periférica que em muitos casos só pode ser levada a cabo via superexploração do trabalho e uso recorrente da mão de obra barata de um semiproletariado. Assim, em Wallerstein, a organicidade do Sistema se desdobra destes elos de valorização articulados com as respectivas estruturas estatais do Centro e da Periferia.

Daí que para ele cada Ciclo Hegemônico (Wallerstein, 2013, p.15) - conceito que busca transpor a noção de hegemonia de Gramsci para as relações internacionais - sempre estará ancorado nas trocas desiguais entre Centro e Periferia. Na história do Sistema-Mundo, dificuldades não apenas econômicas, mas também sociais e políticas que acarretam em perda de legitimidade, debilitam a pujança dos polos centrais e favorecem a sua substituição por novas regiões mais dinâmicas. Ao mesmo tempo, Wallerstein salienta que tal sucessão de Ciclos tem como corolário a contínua expansão da fronteira do Sistema. E aqui também a Periferia cumpre uma outra função crucial na medida em que absorve exportações de capital em busca de mão de obra e custos mais baixos, servindo como refúgio para as crises de lucratividade nas regiões mais desenvolvidas. Incorporando gradualmente uma fronteira externa que servia como sua válvula de escape, a cada Ciclo Hegemônico o Sistema ganhava em amplitude geográfica tornando-se cada vez mais universal. 
Todavia, nas últimas décadas haveria uma mudança de qualidade. Os EUA estariam em declínio, mas isso não implicava um novo hegemón. E, mais importante, tal transformação qualitativa estaria entravando o próprio evolver do Sistema-Mundo. A manutenção de um nível de lucratividade que suportasse o processo contínuo de acumulação estaria esbarrando em três obstáculos crescentes (Wallerstein, 2004, p.66). Em primeiro lugar, tornava-se mais difícil agora dirimir as pressões salariais internas nas regiões mais ricas com a deslocalização da produção para as regiões periféricas. Estaria em curso um processo de desruralização do mundo, minando aquele potencial de mão de obra que sempre servira como fronteira de expansão capitalista a baixo custo. Com as reservas de trabalho sendo comprimidas, os pleitos dos assalariados por maior participação na renda tornavam-se mais difíceis de serem negados, acarretando "um aumento do nível salarial como percentagem dos custos de produção, calculado em média na economia-mundo como um todo" (Ibidem, p. 66). Em segundo lugar, os novos padrões produtivos estariam tornando crítica a situação ambiental do mundo. E na medida em que as empresas (ou o Estado por meio de tributação) precisam suportar os custos de tais externalidades negativas, isso não pode deixar de debilitar os lucros e a acumulação. Por fim, um terceiro fator de pressão sobre a lucratividade adviria da questão fiscal. O aumento das pressões democráticas em todos os países por serviços públicos estaria sobrecarregando os gastos estatais, aumentando a necessidade de tributação sobre o excedente acumulável.

Vale notar aqui que Wallerstein $(2001,65-82)$ entrelaça a questão das barreiras à acumulação com a dimensão cultural e dos valores. Pois é possível depreender de sua análise que, quanto mais o sistema se globaliza e se mercantiliza, mais se espraia uma dada mentalidade no seu interior que intensifica as pressões - do Centro à Periferia - por mais e melhores serviços governamentais e salários. Poderíamos aqui acrescentar ainda que a uniformização mundial dos costumes generaliza tanto um padrão de consumo predatório ao ambiente como também, por outro lado, a consciência da necessidade de se custear os cuidados de preservação do planeta oriundos desse mesmo padrão. Destarte, Wallerstein atribui grande importância às mudanças de mentalidade e de atitude na causação de um permanente profit squeeze. A universalização de determinadas ideias, produto do próprio sucesso histórico do Sistema-Mundo, estaria trazendo sérios obstáculos para a sua legitimidade, colocando em xeque a sua continuidade. Não é à toa que ele endosse o vaticínio de Schumpeter (1961. p.154164) de que o capitalismo sucumbiria não pelos seus fracassos mas sim pelos seus sucessos (Wallerstein, 2004, p. 74). Leia-se, para ambos, o capitalismo tenderia a se esfumar, em grande parte, por conta da deslegitimação advinda de sua própria ordem institucional em função de um processo de racionalização generalizado da vida.

Destarte, Wallerstein há de se concentrar na dificuldade de compatibilizar a acumulação de capital com as demandas da sociedade na contemporaneidade. Aqui as mobilizações de 1968 são um marco (Ibidem, p. 58). Seu caráter mundial denota a insatisfação e a desilusão para com as expectativas geradas no pós-guerra no Primeiro, Segundo e Terceiro Mundos. Com as frustrações acumuladas em relação aos desejos sociais crescentes, o próprio Estado Nacional perde legitimidade, dificultando os consensos. A ideologia do 
A crise contemporânea do capitalismo: reflexões a partir de um debate com as abordagens sistêmicas...

desenvolvimento e progresso torna-se obsoleta, ao passo que o Estado perde força para domar as resistências. Com isso ele tem mais dificuldades para garantir os pressupostos da acumulação e os privilégios monopolistas. (Ibidem, p. 72). Ou seja, tudo conspira para intensificar a crise. Em tese, tal crise poderia ser evitada para Wallerstein com uma articulação consciente do "andar de cima". Mas ele não crê nisso argumentando que o grau de acordo necessário para tanto seria obliterado pela miríade de interesses particulares imediatos dos principais atores. ${ }^{26}$

Wallerstein fornece um quadro útil para pensarmos os limites postos ao SistemaMundo. No entanto, sua explicação das causas de tais limites não é de todo satisfatória. Como vimos, Wallerstein enfatiza a forma pela qual a racionalidade que se difunde com a expansão do Sistema impulsiona um conjunto de exigências e expectativas que se chocam com a lucratividade capitalista já nos dias atuais e mais ainda num cenário prospectivo. Sem negar tal ideia em si, é preciso matizá-la. Em primeiro lugar, para além das pressões sociais, a queda na lucratividade no longo prazo pode estar alicerçada em outros motivos. Em segundo lugar, há também processos em curso que atuam no sentido de dirimir em parte as resistências sociais. Senão, vejamos. Nos parece controversa a ideia de que a baixa da lucratividade sistêmica tem como uma de suas causas o reforço dos assalariados e de seu nível salarial. A própria transnacionalização do capital - tida por Wallerstein como elemento de proletarização generalizada e do reforço do espírito combativo dos trabalhadores - ao jogar regiões umas contra as outras, acaba por debilitar a posição dos trabalhadores. ${ }^{27}$ Fenômenos como desemprego estrutural, precarização e crescimento da informalidade do trabalho vão no mesmo sentido. ${ }^{28}$ A tendência à substituição de "trabalho vivo" por "trabalho morto" produto da lógica concorrencial do capitalismo também tende a enfraquecer a barganha salarial. E justamente esse último processo que tende a aumentar o peso do capital constante vis-à-vis o capital variável, poderia melhor conciliar a baixa da lucratividade com a ausência de fortes pressões altistas salariais (ou ainda o predomínio de pressões baixistas) em relação aos custos totais de produção. Isso se casaria melhor inclusive com as estimativas de longo prazo que vimos mais acima com Roberts e Kliman que afirmam que a queda secular na lucratividade nos países ricos deve ser creditada a um aumento no longo prazo da composição orgânica que sobrepujou em larga escala o aumento ocorrido na taxa de mais valia. Mais ainda, num cenário prospectivo, com a generalização da "contradição em processo" este fenômeno poderia ganhar ainda mais proeminência, colocando mais lenha na crise de lucratividade capitalista. ${ }^{29}$ Neste olhar

(26) Para Wallerstein "um motorista prudente dirigiria muito mais devagar nestas circunstâncias. Mas não existe um motorista prudente na economia-mundo capitalista." (Ibidem, 75).

(27) Sobre os efeitos desfavoráveis aos trabalhadores a partir da formação de um exército mundial de reserva ver Chesnais (2016, p. 41-43)

(28) Botelho (2016, p. 18) apoiado em dados da OIT aponta que atualmente "63 \% da força de trabalho global atual está em situação de desemprego, desencorajada (desistiu de procurar emprego) ou se trata de "empregados vulneráveis", isto é, trabalhadores por conta própria, trabalhadores sem rendimento, membros de cooperativas de produtores etc."

(29) Tal conjectura se apoia na seguinte proposição de Marx esmiuçada por Rosdolsky (2001, p. 197-200). Porquanto não há limites objetivos para o aumento da composição orgânica, a extração de mais-valia relativa que poderia conter a queda da lucratividade tem limites progressivamente intransponíveis. Sinteticamente, aumentos de produtividade sucessivos de igual 
distinto, o problema maior estaria na própria incapacidade de expansão do valor e não numa incapacidade dos capitalistas em subtraí-lo aos trabalhadores.

Ressalvas semelhantes podem ser levantadas frente ao seu argumento de esgotamento da fronteira periférica. Mais precisamente, até que ponto a existência de desruralização e a difusão de uma cultura mais reivindicatória em áreas outrora tradicionalistas estariam configurando obstáculos para a lucratividade e acumulação de capital? Não se trata aqui de negar que tal fator possa de fato jogar seu papel como barreira, mas por certo é preciso balizálo. Como vimos, uma das facetas da crise estrutural do capitalismo é a tendência ao colapso dos processos de modernização periférica que implica em dificuldades suplementares de integração à produção dos trabalhadores da periferia. Isso se casa com o fato de que no interior do Sistema existam sim regiões que permanecem prenhes de mão de obra potencialmente utilizável, mas que nem por isso irão absorver processos de acumulação de capital. Dadas as transformações da estrutura produtiva que vão no sentido de intensificar o uso da automação e da ciência como força produtiva, em muitos casos, nem mesmo a superexploração de mão de obra pode viabilizar todo um conjunto de empreendimentos cuja estrutura tecnológica e monopolizada hodierna prescinde de tal atributo. ${ }^{30}$ Desse ponto de vista, o problema não seria tanto a impossibilidade da expansão da fronteira periférica per se mas sim a própria ausência de funcionalidade de tal expansão dada a lógica contemporânea do capital.

Tampouco se afigura totalmente justificada a tese de que as pressões fiscais vigentes teriam como motor os pleitos populares. A crise fiscal e explosão das dívidas públicas certamente são elementos importantes da crise estrutural, mas elas parecem ter também outras origens. Em primeiro lugar a capacidade de arrecadação do Estado cai justamente porque a dinâmica de acumulação e crescimento é retardada. Este fator, somado aos salvamentos patrimoniais e às políticas de estímulo diante das crises mais frequentes, agravam a questão. Ademais, num quadro de concorrência mundializada e financeirização, os Estados são coagidos a reduzir o nível de tributação sobre os capitalistas, sob a ameaça permanente de fugas abruptas ou retração de investimentos. Essa pressão sobre os erários - que vem justamente da dinâmica contemporânea do capitalismo em crise - aumenta as pressões para que se diminua a destinação dos fundos públicos ao bem-estar social, a despeito dos clamores populares crescentes $^{31}$. Este processo de canalização dos fundos públicos ao capital ganha relevo na

proporção trarão aumentos cada vez menores de mais-valia relativa: "Quanto mais desenvolvido é o capital(...) tanto mais formidavelmente terá de desenvolver a produtividade para valorizar-se(...) em proporção cada vez menor” (MARX apud ROSDOLSKY, 2001, p. 200).

(30) Milios; Sotiropoulos (2009, p. 147-166) mostram bem que mesmo com diferenciais salariais substantivos os fluxos de Investimento Externo Direto têm se concentrado em larga escala nos próprios países ricos, com a exceção de alguns países asiáticos. Por não conseguirem internalizar as exigências das novas estruturas produtivas, muitos países estariam passando por um processo de marginalização internacional.

(31) Segundo o IIF, o aumento das dívidas públicas tem sido o principal fator de crescimento do endividamento global. Valor (2017). Sobre os efeitos fiscais das políticas de salvamento após a crise global de 2008 ver Wolf (2014, p.53-57). E, por fim, a nova reforma fiscal de Trump aprovada no final de 2017 nos parece ser exemplo sintomático da destinação de fundos públicos para as grandes corporações em detrimento dos serviços públicos. 
própria medida em que se difunde a ideia de que a sobrevivência da própria sociedade depende da sobrevivência dos "mercados". E esta ilustrativa inversão fetichista, tende a ser um fator que limita as resistências propugnadas por Wallerstein.

As ponderações acima que sustentamos, em parte como adendo, mas também em parte como crítica à descrição das causas da crise sistêmica em Wallerstein, nos permitem avançar uma última questão. Como vimos, ele confere especial importância para o fato do capitalismo instituir e universalizar uma dada racionalidade que aumenta as pressões sobre o Sistema. Sem rejeitar esta ideia in totum, avançamos aqui uma outra proposição. Em paralelo à razão consciente da sociedade com suas demandas e exigências crescentes, o mesmo desenvolvimento capitalista também generaliza uma outra razão "cega", própria ao capital, e cuja internalização pela sociedade não aflora como uma escolha consciente, mas sim como uma imposição derivada das formas de socialização vigentes. No contexto de crise e tensões que Wallerstein apresenta de forma pertinente, esta outra razão tende a intensificar a incerteza e a irracionalidade ${ }^{32}$ no interior do Sistema. Deste ponto de vista, mesmo que fosse possível um acordo entre as diferentes elites do "andar de cima" para se contornar os dilemas em curso, isto é, mesmo se existissem os "motoristas prudentes" que Wallerstein crê inexistentes, o Sistema permaneceria informado por uma dinâmica que suscita uma incontrolabilidade crescente, para além das intenções de seus agentes.

\section{Considerações finais}

Através do debate com Arrighi, Fiori e Wallerstein, elencamos certos elementos que, pensamos, são de especial relevância para se pensar o capitalismo contemporâneo. Sem a pretensão de uma interpretação acabada dos processos em curso, buscamos ilustrar uma dinâmica global disruptiva, permeada por imprevisibilidade e ingovernabilidade crescentes, e informada por um contexto de crise estrutural. Crise esta que se explicita com as dificuldades para a retomada de um padrão de acumulação sustentável, a financeirização e endividamento em grande escala como fenômenos perenes, mudanças nos padrões tecnológicos e de competição que não apenas diminuem a capacidade de integração social como também tendem a marginalizar regiões inteiras do globo. Ligado a um conjunto de compulsões e imperativos fetichistas, tal cenário de crise acentua a irracionalidade e reduz as margens de manobra disponíveis no interior do Sistema.

Ao mesmo tempo, na medida em que as abordagens sistêmicas buscam refletir a dinâmica do capitalismo dentro de um quadro de análise que envolve diferentes esferas da vida social, cremos que o debate com tais abordagens pode abrir um leque profícuo de questões a serem investigadas. Dito de outra forma, tanto através da exposição quanto também das críticas cabíveis de tais abordagens, pensamos que é possível descortinar determinadas facetas e

(32) A própria crise ecológica talvez possa melhor apreendida por esta via. Temos dúvidas se é lícito dizer que as tentativas de se lidar com tal crise estariam por si arrefecendo a lucratividade. Já a irracionalidade da lógica da acumulação como fim em si, fator que Wallerstein também salienta, parece estar de forma inequívoca degradando a situação ambiental na Terra. 
dimensões relevantes da crise contemporânea do capitalismo. Assim, em Arrighi, buscamos contrapor a força de seu argumento sobre a insustentabilidade da situação do atual SistemaMundo a partir da bifurcação inédita entre poder político e econômico, com elementos que problematizam a possibilidade de uma nova institucionalização do capitalismo em linha com uma "sociedade de mercado mundial" ancorada na China. Em Fiori, endossamos a sua visão que prioriza as repetidas desordem e conflitos em escala global, ao passo que tentamos indicar que tal cenário seria melhor explicado não por uma nova expansão do Sistema mas sim por uma dinâmica de crise. Em Wallerstein, buscamos adendar e reformular em parte sua descrição da crise sistêmica a partir de desenvolvimentos que emanam das próprias compulsões do capital como "sujeito automático".

Feito tal percurso, avançamos uma última consideração. $\mathrm{O}$ enfoque adotado neste artigo, ao dar importância ao processo de imposição do capital e seus dispositivos de dominação social abstrata, não se configura apenas numa dada opção metodológica entre tantas. Mais que isso, cremos tratar-se de um método adequado ao seu objeto. Uma forma de ilustrar isso é recapitular a sugestão de Wallerstein de que 1968 seria um marco para o início da crise do Sistema. Seria a partir de então que haveria um processo crescente de deslegitimação dos Estados e também a explicitação da "traição" das perspectivas modernizantes que lastreavam de formas diferenciadas a ideia de progresso e desenvolvimento nos três "mundos" de então. Entretanto, a inflexão proposta por Wallerstein também pode ser lida num outro sentido. A despeito das diferenças entre tais perspectivas modernizantes, havia um elemento que as unia. Seja no Primeiro Mundo com o modelo fordista-keynesiano, no Segundo Mundo com o chamado "socialismo real" e no Terceiro Mundo com as experiências de modernização desenvolvimentistas, as práticas de planejamento, controle e regulação apoiadas no Estado se faziam presentes de forma conspícua. O fato de que tais práticas tenham perdido sobremaneira seu lugar de forma tão abrangente não parece ser algo fortuito. Não é nosso intuito esmiuçar tema tão complexo. Deixamos apenas uma observação. A ascensão daquilo que tem sido chamado de neoliberalismo tem acarretado um conjunto de transformações que vão no sentido de intensificar o poder "cego" dos mercados sobre as diferentes esferas da vida. O suporte principal de tal processo não deve ser atribuído, a nosso ver, à intencionalidade de Estados, classes ou grupos sociais por mais poderosos que estes sejam e independentemente do fato de que os vencedores globais ainda sejam uma pequenina cúpula do "andar de cima" braudeliano. Alternativamente, nos apoiamos aqui na formulação de Dardot e Laval de que o neoliberalismo seria melhor descrito como a própria razão do capitalismo contemporâneo que "tende a estruturar e organizar não apenas a ação dos governantes, mas até a própria conduta dos governados(...) e tem como característica principal a generalização da concorrência como norma de conduta e da empresa como modelo de subjetivação". (Dardot; Laval, 2016, p. 17). Uma apreensão adequada do capitalismo contemporâneo pressupõe uma reflexão tanto das origens como das consequências desta razão de caráter pervasivo que molda a prática dos indivíduos, instituições e dos próprios Estados sem que para tanto ela tenha sido originada de um projeto consciente e deliberado. Daí que 
nos pareça adequado um enfoque que ponha em tela a dinâmica posta pelos mecanismos fetichistas produzidos pela lógica do capital neste século XXI.

\section{Referências bibliográficas}

ARIENTE, W. L.; FILOMENO, F. A. Economia política do moderno sistema mundial: as contribuições de Wallerstein, Braudel e Arrighi. In: Ensaios FEE, Porto Alegre, v. 28, 2007

ARRIGHI, G. O longo século XX. Dinheiro, poder e as origens de nosso tempo. Rio de Janeiro: Contraponto; São Paulo: UNESP, 1996.

ARRIGHI, G; Silver, B. J. Caos e governabilidade no moderno sistema mundial. Rio de Janeiro: UFRJ-Contraponto, 2001.

ARRIGHI, G. Adam Smith em Pequim: origens e fundamentos do século 21. São Paulo, Boitempo, 2008

ARRIGHI, F. Postscript to the Second Edition of The Long Twentieth Century. 2010.

ARRIGHI, G; SILVER, B. J. O fim do longo século XX. In: In: O Brasil e o capitalismo histórico: passado e presente na análise dos Sistemas-Mundo. Filomeno, F.A, Vieira, P.A., Vieira, R. L.(Orgs.) Cultura Acadêmica, 2012

BRENNER, R. O Boom e a Bolha: Os Estados Unidos na Economia Mundial. Rio de Janeiro: Record, 2003

BOTELHO. M. L. Crise do trabalho hoje: desenvolvimento tecnológico, instabilidade do emprego e crise do capitalismo. In: Acesso Livre, n.5, 2016

BRAUDEL, F. A dinâmica do capitalismo. Rio de Janeiro: Rocco, 1987

BRAUDEL, F. Civilização material, economia e capitalismo. Séculos XV a XVIII (3 vols.). São Paulo: Martins Fontes, 1995.

CHESNAIS, F. Finance Capital Today: Corporations and Banks in the Lasting Global Slump. Historical Materialism, 2016.

COLLINS, R. The end of middle class work: no more escapes. In: Does capitalism have a future?, Wallerstein, I (org.), Oxford, 2013

CHENGSI, Z. Dangers of 'excessive financialization' in Chinese economy. 2016. Disponível em http://www.china.org.cn/opinion/2016-01/01/content_37433275.htm

DARDOT, P; LAVAL, C. A nova razão do mundo: ensaios sobre a sociedade neoliberal. São Paulo: Boitempo, 2016.

EICHENGREEN, B. Privilégio Exorbitante: a ascensão e queda do dólar e o futuro do Sistema Financeiro Internacional. Rio de Janeiro: Elsevier, 2011

ELIAS, Norbert. O processo civilizador. Rio de Janeiro: Jorge Zahar Editor, 1976, vol.2 
Daniel Feldmann

Financial Times. Chinese manufacturing jobs vanish as robots take over. 2017. Disponível em https://www.ft.com/content/f4444146-f84f-11e6-9516-2d969e0d3b65

FIORI, J. L. F. Sobre o poder global. In: Novos Estudos, n. 73, 2005

FIORI, J. L. F; Medeiros, C.A. de; Serrano, F. P. O mito do colapso do poder americano. Rio de Janeiro: Record, 2008

FIORI, J. L. F. História, Estratégia e Desenvolvimento: para uma geopolítica do capitalismo. São Paulo: Boitempo, 2014.

GONTIJO, C.; OLIVEIRA, F. A. Subprime: os 100 dias que abalaram o capital financeiro mundial e os efeitos da crise sobre o Brasil. Belo Horizonte, 2011.

GUTTMAN, R. Uma introdução ao capitalismo dirigido pelas finanças. Novos estudos, São Paulo, n. 82, 2008.

HARVEY, D. O novo imperialismo. Loyola: São Paulo, 2010.

HOBSBAWM, E. Globalização, democracia e terrorismo. São Paulo: Companhia das Letras, 2007.

HUSSON, M. The shape of the coming crisis. Disponível em http://hussonet.free.fr/cqveng.pdf

KLIMAN, A. The failure of capitalist production. Underlying Causes of the Great Recession. PlutoPress: 2012

KLIMAN, A. A grande recessão e a teoria da crise em Marx. In: Outubro, edição 24, 2015.

KURZ, R. O colapso da modernização: da derrocada do socialismo de caserna à crise da economia mundial. Rio de Janeiro: Paz e Terra, 1993.

KURZ, R. Imperialismo de crise. In: Poder mundial e dinheiro mundial: crônicas do capitalismo em declínio. Rio de Janeiro: Consequência Editora, 2015

MAITO, E. "The Historical Transience of Capital: The Downward Trend in the Rate of Profit since XIX Century." Buenos Aires, Argentina, 2014. Disponível em http://gesd.free.fr/maito14.pdf.

MARIUTTI, E. B. A perspectiva dos sistemas-mundo: fundamentos e tendências. In: $O$ Brasil e o capitalismo histórico: passado e presente na análise dos Sistemas-Mundo. Filomeno, F.A, Vieira, P.A., Vieira, R. L.(Orgs.) Cultura Acadêmica, 2012

MARIUTTI, E. B. A esquerda e o desenvolvimentismo: notas sobre o pensamento de José Luís Fiori. In: Rede Desenvolvimentista, 2012 b.

MARX, K. O Capital: crítica da economia política. São Paulo: Nova Cultural, 1985. 5v.

MARX, K. Grundrisse. São Paulo: Boitempo, 2012 
A crise contemporânea do capitalismo: reflexões a partir de um debate com as abordagens sistêmicas...

MILIOS, J; SOTIROPOULOS, D. Rethinking Imperialism: a Study of Capitalist Rule. Palgrave Macmillan, 2009.

OLIVEIRA, F.de. Crítica à razão dualista. O ornitorrinco. São Paulo: Boitempo, 2002

PAULANI, L. Acumulação sistêmica, poupança externa e rentismo: observações sobre o caso brasileiro. In: Estudos avançados 27 (77), 2013

POSTONE, M. Tempo, Trabalho e Dominação Social. São Paulo: Boitempo, 2014

POSTONE, M. La teoria critica del capital. In: Constelaciones: revista de teoria critica. 2016

POSTONE, M. The Current Crisis and the anachronism of value: a Marxian reading. In: Continental Thought \& Theory. 2017

ROBERTS, M. The long depression: what happened and what comes next. Chicago, Haymarket, 2016.

ROSDOLSKY, R. Gênese e estrutura de O capital de Karl Marx. Rio de Janeiro: Contraponto, 2001

SCHOLZ, R. Cristóvão Colombo forever? Para a crítica das atuais teorias da colonização no contexto do "Colapso da modernização". Exit, jan. 2016. Disponível em http://www.obecoonline.org/roswitha_scholz24.htm

SCHUMPETER, J. A. Capitalismo, Socialismo e Democracia. Rio de Janeiro: Fundo de Cultura, 1961

STREECK, W. Como será a nossa sociedade nos próximos decênios? 2017. Disponível em https://eleuterioprado.files.wordpress.com/2017/01/como-serc3a1-a-nossa-sociedade-nosprc3b3ximos-decc3aanios.pdf

Valor. Dívida global alcança recorde de 325\% do PIB mundial em 2016, diz IIF. 2017. Disponível em http://www.valor.com.br/financas/4925286/divida-global-alcanca-recorde-de325-do-pib-mundial-em-2016-diz-iif

VIEIRA, C.A.C. Antigo Regime e transição: breve estudo em torno do capital mercantil e do absolutismo. Tese de doutoramento, IE, UNICAMP, 2012.

WALLERSTEIN, I. The capitalist world-economy. Essays by Immanuel Wallerstein. Cambridge: Cambridge University Press, 1979.

WALLERSTEIN, I. Capitalismo histórico \& civilização capitalista. Rio de Janeiro: Contraponto, 2001.

WALLERSTEIN, I. O declínio do poder americano. Rio de Janeiro: Contraponto, 2004.

WALLERSTEIN, I. World-systems analysis: an introduction. Durham: Duke University Press, 2005. 
Daniel Feldmann

WALLERSTEIN, I. A Análise dos Sistemas-Mundo como movimento do saber. In: $O$ Brasil e o capitalismo histórico: passado e presente na análise dos Sistemas-Mundo. Filomeno, F.A, Vieira, P.A., Vieira, R. L. (Orgs.) Cultura Acadêmica, 2012

WALLERSTEIN, I. Structural crisis, or why capitalists may no longer find capitalism rewarding. In: Does capitalism have a future? Wallerstein, I (org.), Oxford, 2013

WIPO. World Intellectual Property Indicators 2017. Geneva: World Intellectual Property Organization, $2017 . \quad$ Disponível em http://www.wipo.int/edocs/pubdocs/en/wipo_pub 941 2017.pdf

WOLF, M. As transições e os choques. São Paulo: Companhia das Letras, 2014

WOOD, E. Império do capital. São Paulo: Boitempo, 2014. 